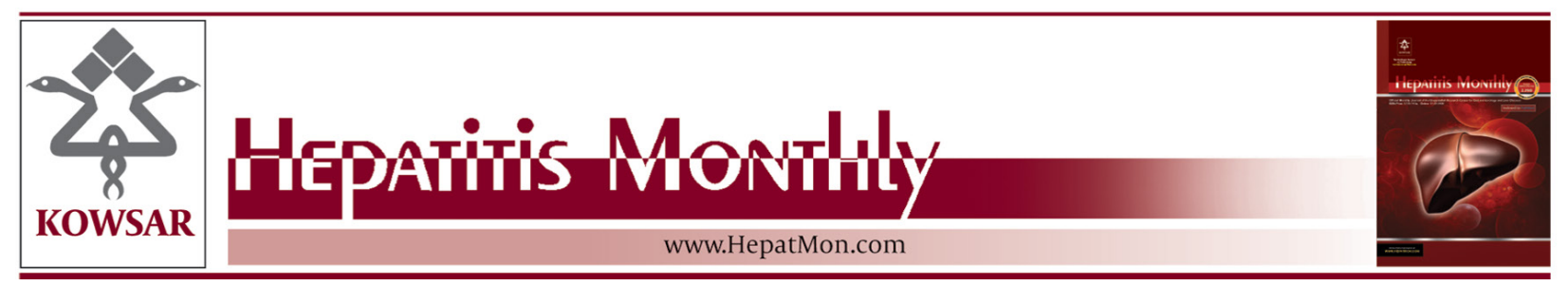

\title{
Controversial Report Regarding Seroprevalence of Hepatitis B and C Viruses Among Hemodialysis Patients In Kerman Province, South-East Iran
}

\author{
Mojgan Noroozi Karimabad ${ }^{1}$, Gholamhossein Hassanshahi ${ }^{1}$, Mohammad Kazemi Arabab- \\ $\operatorname{adi}^{2, *}$ \\ ${ }^{1}$ Molecular Medicine Research Center, Rafsanjan University of Medical Sciences, Rafsanjan, IR Iran \\ ${ }^{2}$ Immunology of Infectious Disease Research Center, Rafsanjan University of Medical Sciences, Rafsanjan, IR Iran \\ *Corresponding author: Mohammad Kazemi Arababadi, Immunology of Infectious Disease Research Center, Rafsanjan University of Medical Sciences, Raf- \\ sanjan, IR Iran. Tel.: +98-09132926113, Fax: +98-3915225209, E-mail: dr.kazemi@rums.ac.ir.
}

Keywords: Hepatitis B Virus; Hepatitis C; Epidemiology; Renal Dialysis

\section{Dear Editor,}

We read carefully the article by Zehedi et al., (1) which determined the prevalence of hepatitis B (HBV), C(HCV), and $\mathrm{D}$ (HDV) viruses as well as the human immunodeficiency virus (HIV) in hemodialysis (HD) patients within Kerman province, located in south-east region of Iran (1). It is now well established that the prevalence of various types of hepatitis viruses among HD patients is higher than the general population (2). According to the important role playing by viral infections in the pathogenesis of HD health status, the prevalence of the viral infections was evaluated in the HD patients by the authors. They have reported that the prevalence of HBV and HCV was moderate to low, while, HIV-Ab and HDV-Ab were both negative in all patients of Kerman province (1). The Authors of this letter believe that zahedi and co-worker`s results need to be interpreted more cautiously, because possible confounders and limitations of their study need to be considered. Zahedi et al., have evaluated the prevalence of HBV and also HCV using ELISA dependent technique and studied the HCV-RNA and HBV-DNA in the HCV-Ab and HBsAg positive patients, respectively, via Real-Time PCR. Based on the previous reports, it is obvious that a proportion of the HCV infected patients are unable to produce detectable antibody against HCV due to several reasons including humeral immunodeficiency (3), impaired Th2 system (4) as well as insufficient stimulation by innate immunity $(5,6)$. Additionally, the infected patients need enough time from the initiation point of the infection to produce anti-HCV antibodies (latent phase). Therefore, considerable cases of HCV infected individuals have been missed where merely ELISA technique is used to detect HCV infection. In contrast with Zahedi et al.' results, our

Article type: Letter; Received: 20 Jun 2012, Revised: 10 Jul 2012, Accepted: 30 Jul 2012; DOI: 10.5812/hepatmon.7046

-Please cite this paper as:

Noroozi Karimabad M, Hassanshahi G, Arababadi MK. Controversial Report Regarding Seroprevalence of Hepatitis B and C Viruses Among Hemodialysis Patients In Kerman Province, South-East Iran. Hepat Mon. 2012;13(3):e7046. DOI: 10.5812/hepatmon.7046

-Copyright (C) 2013, Kowsar Corp.; Published by Kowsar Corp.

This is an Open Access article distributed under the terms of the Creative Commons Attribution License (http://creativecommons.org/licenses/by/3.0), which permits unrestricted use, distribution, and reproduction in any medium, provided the original work is properly cited. 
research team has reported already a high rate may be the cause of HCV infection in the HD patients within Kerman province of Iran (2). Interestingly, we have used RT-PCR to detect HCV-RNA in the patients, hence; it is likely that the prevalence of HCV infection may be in contrast to Zahedi et al., which is reported not following a moderate to low fashion in Kermanian HD patients. The controversy can also be considered for prevalence of HBV infection in the HD patients. We have also previously demonstrated that the prevalence of occult HBV infection (OBI), HBsAg-/HBVDNA+ patients, was high in a population of Iranian blood donors, hence, again it seems that the prevalence of this form of disease could be elevated in the HD patients, who are among the mostly recipients of blood and its components. In parallel with our claim, several researchers reported this form of disease in the Iranian and worldwide HD patients (7-9). Due to the fact that, OBI is a form of hepatitis $B$, hence, evaluation of the HBsAg cannot be sufficient for reporting of HBV infection prevalence in the HD patients and the role played by OBI in the spread of infection in the HD patients may need more attentions. Finally, in order to collect more accurate and valid data regarding the real prevalence of HBV and HCV infection, we suggest re-evaluating the Kerman province HD patients using quantitative PCR technique.

\section{Authors' Contribution}

All of authors were involved in all steps of the manuscript preparation.

\section{Financial Disclosure}

None Declared.

\section{References}

1. Zahedi MJ, Darvish Moghaddam S, Alavian SM, Dalili M. Seroprevalence of Hepatitis Viruses B, C, D and HIV Infection Among Hemodialysis Patients in Kerman Province, South-East Iran. Hepa Mon. 2012;12(5):339-43.

2. Arababadi MK, Hassanshahi G, Yousefi H. HBV-DNA in hemodialysis patients infected by HCV. Saudi J Kidney Dis Transpl. 2009;20(3):398-401.

3. Pesanti EL. Immunologic defects and vaccination in patients with chronic renal failure. Infect Dis Clin North Am. 2001;15(3):81332.

4. Liu ML, Xu G, Xue SR, Zhong XC, Chen GX, Chen ZJ. Plasma levels of Th1/Th2 type cytokine are associated with change of prolactin and GH/IGF-I in hemodialysis patients. Int J Artif Organs. 2008;31(4):303-8

5. Chonchol M. Neutrophil dysfunction and infection risk in endstage renal disease. Semin Dial. 2006;19(4):291-6.

6. Eleftheriadis T, Liakopoulos V, Leivaditis K, Antoniadi G, Stefanidis I. Infections in hemodialysis: a concise review. Part II: blood transmitted viral infections. Hippokratia. 2011;15(2):120-6.

7. Abu El Makarem MA, Abdel Hamid M, Abdel Aleem A, Ali A, Shatat $M$, Sayed D, et al. Prevalence of occult hepatitis B virus infection in hemodialysis patients from egypt with or without hepatitis $C$ virus infection. Hepat Mon. 2012;12(4):253-8.

8. Altindis M, Uslan I, Cetinkaya Z, Yuksel S, Ciftci IH, Demirturk $\mathrm{N}$, et al. [Investigation of hemodialysis patients in terms of the presence of occult hepatitis B]. Mikrobiyol Bul. 2007;41(2):227-33.

9. Ramezani A, Banifazl M, Eslamifar A, Aghakhani A. Serologica pattern of anti-HBc alone infers occult hepatitis B virus infection in high-risk individuals in Iran. J Infect Dev Ctries. 2010;4(10):658-61. 